\title{
Characterization of Probiotic Properties of Lactic Acid Bacteria Isolated from Yoghurt Available in Bangladesh
}

\author{
Mohammad Shaokat Ali ${ }^{\text {* }}$, Shamima Ahmed ${ }^{2}$, Md. Forhad Uddin ${ }^{3}$, Abdul Matin ${ }^{2}$, \\ Mohammad Sharif Uddin ${ }^{3}$, Nilufa Yeasmin ${ }^{4}$
}

${ }^{1}$ Department of Applied Chemistry and Chemical Technology, Faculty of Food Science and Technology, Chittagong Veterinary and Animal Sciences University, Khulshi, Chittagong-4225, Bangladesh

${ }^{2}$ Department of Food Processing and Engineering, Faculty of Food Science and Technology, Chittagong Veterinary and Animal Sciences University, Khulshi, Chittagong-4225, Bangladesh

${ }^{3}$ Department of Microbiology, University of Chittagong, Bangladesh

${ }^{4}$ Department of Applied Food Science and Nutrition, Faculty of Food Science and Technology, Chittagong Veterinary and Animal Sciences University, Khulshi, Chittagong-4225, Bangladesh

\section{A R T I C L E I N F O}

\section{Research Article}

Received 13 February 2018

Accepted 20 September 2018

Keywords:

Yoghurt

Probiotics

Lactic acid bacteria

Characterization

Isolation

*Corresponding Author:

E-mail: shaokat.fst@gmail.com

\section{A B S T R A C T}

Yoghurt is the common fermented dairy product consumed worldwide and it is considered a potential source of probiotic bacteria (Lactobacilli and Lactococci). To assess the in-vitro probiotic properties of lactic acid bacteria, Lactococcus lactis subsp. lactis, Lactobacillus delbrueckii and Lactobacillus plantarum species isolated from yoghurt sold in different local markets of Chittagong region in Bangladesh were examined by morphological characteristics and biochemical tests. In the preliminary test, all isolates were grown well at acidic $\mathrm{pH}(\mathrm{pH} 3-5)$ while the optimum growth temperature was $37^{\circ} \mathrm{C}$ and better growth was observed in the presence of $1-8 \% \mathrm{NaCl}$ concentrations. In addition, the selected isolates were able to survive up to $3 \%$ bile salt concentrations while the best tolerance was at $1 \%$ bile salt. The strains successfully inhibited the growth of common pathogenic bacteria likely Escherichia coli, Pseudomonas aeruginosa, Salmonella Paratyphi, Staphylococcus aureus and Bacillus subtilis examined by in vitro growth inhibition test. Most of the isolated strains exhibited resistance pattern against ten commonly used antibiotics in foodborne illness in the country. However, the strains in yoghurt sold at Chittagong city have ideal probiotic characteristics and this fermented dairy product could be a potential source of human probiotic bacteria.

DOI: https://doi.org/10.24925/turjaf.v6i11.1544-1549.1856

\section{Introduction}

Yoghurt, a fermented dairy product, is widely consumed all over the world. The lactic acid fermentation of milk lactose produces sour taste of yoghurt which has an effect on milk protein as well as texture of yoghurt (Zourari et al., 1992). Probiotics are live microorganisms thought to be beneficial to the host organism (Aslam and Qazi, 2010). Probiotics are defined as live microorganisms, including Lactobacillus species, Bifidobacterium species and yeasts that may beneficially affect the host upon ingestion by improving the balance of the intestinal microflora. Probiotics are commonly consumed as part of fermented foods with specially added active live cultures; such as in yoghurt, soy yoghurt, or as dietary supplements. With elapse of time, various types of bacteria have been used as probiotics. They have dynamic assistance of the immune system and can facilitate in the dealing of a various conditions such as lactose intolerance, diarrhea (Yan and Polk, 2006), colitis, hypertension, cancer, constipation, food allergies, irritable bowel syndrome and other intestinal tract infection. Probiotic bacteria can produce various compounds such as organic acids, bacteriocins and reuterin. These compounds have inhibitory effects on the growth of pathogenic bacteria (Tambekar and Bhutada, 2010b). Lilly and Stillwell (1965) reported that lactic acid bacteria (LAB) show the probiotic properties and they are Grampositive, non-spore forming, cocci or rods, catalasenegative and can cause lactic acid fermentation. Lactic acid bacteria are naturally occurring and non-pathogenic to human and animals (Patil et al., 2010). Most of the lactic acid bacteria are used as probiotics. Lactobacillus species are most commonly used group within the group LAB for their potential probiotic properties. The growth of a large number of enteric and urinary pathogenic bacteria is suppressed by the adverse effect of lactic acid bacteria (Hutt et al., 2006). Yoghurt made from cow milk is one of the traditional fermented dairy products in Bangladesh and usually consumed as desert by large 
number of population. Yoghurt may contain large number of probiotic bacteria which have the beneficial health effects revealed by the study conducted by Salminen (1996). The aim of this study was to isolate and identify probiotic bacteria from yoghurt and characterize the probiotic properties of the isolates.

\section{Materials and method}

\section{Collection of Samples}

A total 30 different branded yoghurt made from pasteurized cow milk was collected from different super shops. All of the samples were immediately transferred to sterile deMan Rogosa and Sharp (MRS) broth in sterile screw capped test tubes. Then the samples were transported to the laboratory as soon as possible in an insulated foam box with ice to maintain a temperature ranging from $4^{\circ} \mathrm{C}$ to $6^{\circ} \mathrm{C}$.

\section{Isolation and Identification of Lactic Acid Bacteria}

Lactic acid bacteria were isolated from yoghurt by using MRS medium. MRS broth media were inoculated with yogurt sample. About one gram (properly agitated) of each yoghurt sample was inoculated into $100 \mathrm{ml}$ of MRS broth at $\mathrm{pH}$ 6.0. Then the inoculated broth was shaken and incubated at $37^{\circ} \mathrm{C}$ for 24 hours. To obtain pure cultures, the cultures with MRS broth were subjected to make subcultures. Five subcultures were made with MRS broth at $37^{\circ} \mathrm{C}$ under low $\mathrm{pH}(\mathrm{pH}$ 5.0) by using anaerobic jar. Then the bacterial culture was streak onto MRS agar media and incubated at $37^{\circ} \mathrm{C}$ for $24-48$ hours in an inverted position. Finally, the pure whitish single colony of lactic acid bacteria was isolated by examining the colony morphology and some biochemical tests (Gram staining, motility, indole, catalase and oxidase). The isolated bacteria were identified (Table 2) by comparing the investigated characters of the isolates to Bargey's Manual of Determinative Bacteriology, $8^{\text {th }}$ edition (Buchanan and Gibbons, 1974).

\section{Test Pathogens}

Five pathogenic bacteria including both Gram positive (Bacillus subtilis and Staphylococcus aureus) and Gram negative (Escherichia coli, Salmonella paratyphi and Pseudomonas aeruginosa,) bacteria were used in this study.

Screening of the Isolates for Antimicrobial Activity by Agar well Diffusion Method

To evaluate the effects of growth inhibition of the test isolates by agar well diffusion method, Mueller Hinton agar plates were heavily seeded uniformly with the test pathogenic organisms. By using sterile gel cutter well (8 $\mathrm{mm}$ in diameter) was prepared in solid media. The base layer of the well was made by using one drop of melted agar into it and then allowed it to solidify. Then the well was poured with specific amount of culture filtrate $(0.1$ $\mathrm{ml})$ and plates were kept at low temperature $\left(4^{\circ} \mathrm{C}\right)$ for $2-4$ hours to allow maximum diffusion. Then plates were incubated at $37^{\circ} \mathrm{C}$ for $18-24$ hours at inverted position. The antibacterial effect of the isolates was examined by measuring the zone of inhibition (Bauer et al. 1966).

\section{Probiotic Properties of the Isolates}

$p H$ Tolerance: The isolated cultures were inoculated into MRS broth tubes at different $\mathrm{pH}$ ranges, i.e. $\mathrm{pH} 2,3$, $4,5,6$, and 7 and incubated at $37^{\circ} \mathrm{C}$ for $48-72 \mathrm{hrs}$. From each tube $0.1 \mathrm{ml}$ of inoculated culture was poured into MRS agar medium by using pour plate method and incubated at $37^{\circ} \mathrm{C}$ for $48 \mathrm{hrs}$. The growth of different culture on MRS agar media was examined to measure the $\mathrm{pH}$ tolerance of the isolated culture.

Bile salt tolerance: MRS broth was prepared with varying concentration (i.e.; $1.0 \%, 2.0 \%$ and $3.0 \%$ ) of bile salt. Then the medium was dispensed at $10 \mathrm{ml}$ per tube. Inoculation was done with the selected isolates. After inoculation with equal amount of inoculums the tubes were then incubated at $37^{\circ} \mathrm{C}$ for 48 hours. After incubation $0.1 \mathrm{ml}$ of culture from each concentration was used to grow in agar medium by pour plate method. The plates were then incubated at $37^{\circ} \mathrm{C}$ for 24 hours and observed for comparative growth in these plates (Tambekar and Bhutada, 2010a).

Temperature sensitivity: The selected isolates were inoculated into different MRS broth tubes and incubated at different temperatures, i.e. $25,30,37,40$, and $45^{\circ} \mathrm{C}$ for 48 hours. By using pour plate method the isolates then cultured on agar medium. The plates were then incubated at $37^{\circ} \mathrm{C}$ for 24 hours and observed for comparative growth in these plates (Tambekar and Bhutada, 2010a).

$\mathrm{NaCl}$ tolerance: The selected isolate was inoculated with different sterilized MRS broth tubes with different $\mathrm{NaCl}$ concentrations $(1-10 \%)$ and incubated at $37^{\circ} \mathrm{C}$ for 24 hours. After incubation $0.1 \mathrm{ml}$ of culture from each tube was used to grow in agar medium by pour plate method. The plates were then incubated at $37^{\circ} \mathrm{C}$ for 24 hours and observed for comparative growth in these plates (Tambekar and Bhutada, 2010a).

Sugar fermentation test: Isolated organisms were evaluated with fermentation tests of some carbohydrates and sugar alcohols. Different carbohydrates and sugar alcohols were used in this fermentation tests i.e., arabinose, glucose, fructose, galactose, sucrose, lactose, starch and mannitol. The test organisms were inoculated into a broth containing the test sugar and incubated at $37^{\circ} \mathrm{C}$ for 48 to 96 hours. A bright yellow colour indicates the production of enough acid products from fermentation of the sugar to drop the $\mathrm{pH}$ to 6.9 or less. Gas production was investigated with a Durham tube, a small inverted vial filled with the carbohydrate fermentation broth. Yellow colour or yellow colour with gas bubble was considered as positive result and red colour with no gas bubble was considered as negative result.

\section{Assay of Antibiotic Sensitivity Pattern}

To assess the antibiotic sensitivity pattern disk diffusion method was followed. In this method Mueller Hinton plates were prepared and swabbed with suspension of selected isolates with the help of sterile cotton bud. After swabbing the antibiotic disks (azithromycin, ceftriaxome, amoxycillin, kanamycin, cefixime, cephalexin, streptomycin, meropenem, cefaclor, amoxyclav), they were placed on the surface of the plate at equal distance. The plates were then kept at $4{ }^{\circ} \mathrm{C}$ for $1-2$ hours for proper diffusion of antibiotics. The plates were then incubated for $18-24$ hours at $37^{\circ} \mathrm{C}$. The zone of inhibition 
was observed for antibiotic sensitivity or resistance and zone diameter was measured (Bauer et al., 1966).

\section{Results}

Isolation and Identification of Bacteria

Inoculation of collected samples was done with MRS broth in conical flask and incubated at $37^{\circ} \mathrm{C}$ for $18-24$ hours. Then the cultured bacteria were again inoculated with MRS agar and incubated at $37^{\circ} \mathrm{C}$ for $18-24$ hours (Figure 1). Single whitish coloured colonies were collected for investigating their physiological, biochemical and morphological characteristics. In microscopic investigation, the collected isolates were Gram-positive (Figure 2), rod or cocci shaped (Figure 2 and 3 ) non-motile, catalase negative (Table 1).

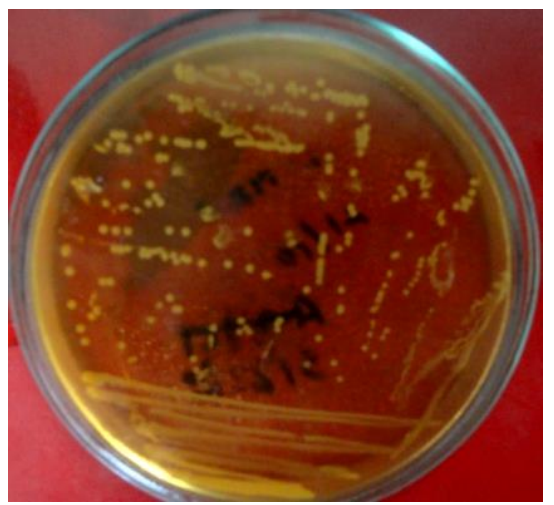

Figure 1 Isolates on MRS agar

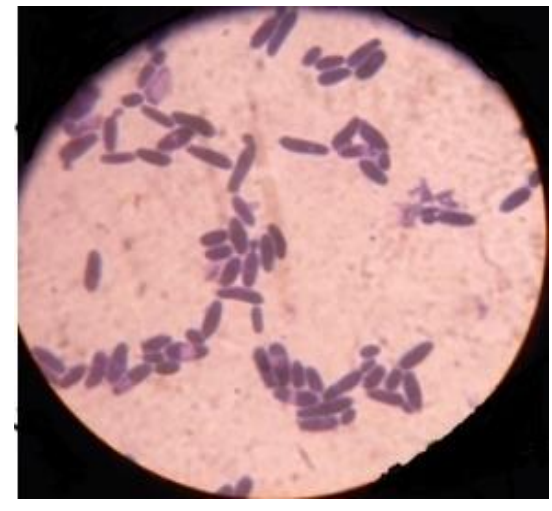

Figure 2 Gram's staining

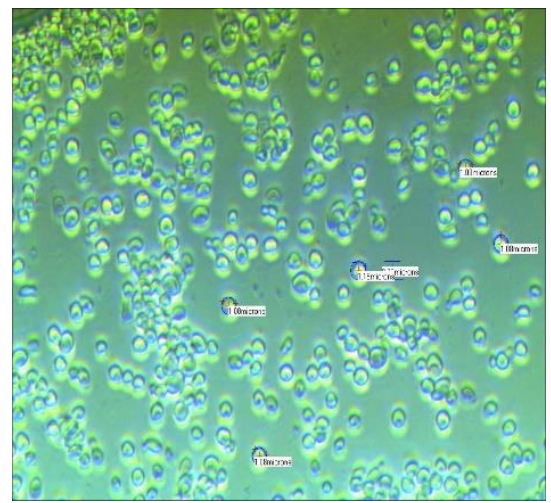

Figure 3 Lactococcus sp. (Phase Contrast Microscope-bright field)

Table 1 Physiological and biochemical tests for identification of the isolates

\begin{tabular}{l|cccccc}
\hline \multicolumn{1}{c}{ Isolates ID } & Gram Staining & Motility Test & Indole Test & Oxidase Test & Catalase Test & Urease Test \\
\hline $\mathrm{YC}_{1}$ & + & - & - & - & - & - \\
$\mathrm{YC}_{2}$ & + & - & - & - & - & - \\
$\mathrm{YC}_{3}$ & + & - & - & - & - & - \\
$\mathrm{YC}_{8}$ & + & - & - & - & - & - \\
$\mathrm{YC}_{10}$ & + & - & - & - & - & - \\
$\mathrm{YN}_{3}$ & + & - & - & - & - & - \\
$\mathrm{YN}_{6}$ & + & - & - & - & - & - \\
$\mathrm{YN}_{7}$ & + & - & - & - & - \\
$\mathrm{YN}_{9}$ & + & - & - & - & - \\
$\mathrm{YCX}_{3}$ & + & - & - & - & - \\
$\mathrm{YCX}_{4}$ & + & - & - & - & - \\
$\mathrm{YCX}_{6}$ & + & - & - & - & - \\
$\mathrm{YCX}_{7}$ & + & - & - & - & - \\
$\mathrm{YCX}_{9}$ & + & - & - & - & - \\
$\mathrm{YCX}_{10}$ & + & - & - & - & - & - \\
\hline $\mathrm{N}_{4}$ & + & - & - & - & - & - \\
\hline
\end{tabular}

Note: + = Positive; - = Negative

Table 2 Identified species of the lactic acid bacteria

\begin{tabular}{l|l}
\hline Isolate ID & Species \\
\hline $\mathrm{YC}_{1}$ & Lactococcus lactis subsp. lactis \\
$\mathrm{YC}_{2}$ & Lactococcus lactis subsp. lactis \\
$\mathrm{YC}_{3}$ & Lactococcus lactis subsp. lactis \\
$\mathrm{YC}_{8}$ & Lactococcus lactis subsp. lactis \\
$\mathrm{YC}_{10}$ & Lactobacillus delbrueckii \\
$\mathrm{YN}_{3}$ & Lactobacillus plantarum \\
$\mathrm{YN}_{6}$ & Lactobacillus plantarum \\
$\mathrm{YN}_{7}$ & Lactococcus lactis subsp. lactis \\
$\mathrm{YN}_{9}$ & Lactococcus lactis subsp. lactis \\
$\mathrm{YCX}_{3}$ & Lactococcus lactis subsp.lactis \\
$\mathrm{YCX}_{4}$ & Lactococcus lactis subsp. lactis \\
$\mathrm{YCX}_{6}$ & Lactobacillus delbrueckii \\
$\mathrm{YCX}_{7}$ & Lactococcus lactis subsp. lactis \\
$\mathrm{YCX}_{9}$ & Lactococcus lactis subsp. lactis \\
$\mathrm{YCX}_{10}$ & Lactobacillus delbrueckii \\
\hline
\end{tabular}


Table 3 Antibacterial activity of the selected isolates

\begin{tabular}{|c|c|c|}
\hline Isolates & Pathogenic bacteria & Zone of inhibition (mm) \\
\hline \multirow{5}{*}{ Lactococcus lactis subsp. Lactis $\left(\mathrm{YC}_{1}\right)$} & Escheriachia coli & 25 \\
\hline & Salmonella Paratyphi & 22 \\
\hline & Staphylococcus aureus & 24 \\
\hline & Bacillus subtillis & 18 \\
\hline & Pseudomonas aeroginosa & 14 \\
\hline \multirow{5}{*}{ Lactobacillus delbrueckii $\left(\mathrm{YCx}_{6}\right)$} & Escheriachia coli & 22 \\
\hline & Salmonella paratyphi & 14 \\
\hline & Staphylococcus aureus & 18 \\
\hline & Bacillus subtillis & 16 \\
\hline & Pseudomonas aeroginosa & 12 \\
\hline \multirow{5}{*}{ Lactobacillus plantarum $\left(\mathrm{YN}_{3}\right)$} & Escheriachia coli & 24 \\
\hline & Salmonella paratyphi & 20 \\
\hline & Staphylococcus aureus & 22 \\
\hline & Bacillus subtillis & 20 \\
\hline & Pseudomonas aeroginosa & 12 \\
\hline
\end{tabular}

Table 4 Assay of antibiotic susceptibility pattern

\begin{tabular}{l|ccc}
\multicolumn{1}{c}{ Antibiotics disk $(\mu \mathrm{g})$} & L. lactis subsp. lactis $\mathrm{YC}_{1}(\mathrm{~mm})$ & L. delbrueckii $\mathrm{YCX}_{6}(\mathrm{~mm})$ & L. plantarum $\mathrm{YN}_{3}(\mathrm{~mm})$ \\
\hline Azithromycin $(\mathrm{AZM})-30$ & $23 \mathrm{~S}$ & $9 \mathrm{R}$ & $26 \mathrm{~S}$ \\
Ceftriaxome (CI)-30 & $11 \mathrm{R}$ & $13 \mathrm{I}$ & $16 \mathrm{I}$ \\
Amoxycillin (AML)-10 & $10 \mathrm{R}$ & $\mathrm{R}$ & $15 \mathrm{I}$ \\
Kanamycin (K)-30 & $20 \mathrm{~S}$ & $\mathrm{R}$ & $21 \mathrm{~S}$ \\
Cefixime (CFM)-5 & $\mathrm{R}$ & $\mathrm{R}$ & $\mathrm{R}$ \\
Cephalexin (CP)-30 & $16 \mathrm{I}$ & $15 \mathrm{I}$ & $10 \mathrm{R}$ \\
Streptomycin (S)-10 & $\mathrm{R}$ & $21 \mathrm{~S}$ & $22 \mathrm{~S}$ \\
Meropenem (MRP)-10 & $28 \mathrm{~S}$ & $\mathrm{R}$ & $37 \mathrm{~S}$ \\
Cefaclor (CF)-30 & $\mathrm{R}$ & $\mathrm{R}$ & $13 \mathrm{I}$ \\
Amoxyclav (AC)-30 & $21 \mathrm{~S}$ & $32 \mathrm{~S}$ & $37 \mathrm{~S}$ \\
\hline
\end{tabular}

$\mathrm{S}=$ Sensitive; $\mathrm{R}=$ Resistant; I = Intermediate

Table 5 Growth performance of the selected isolates

\begin{tabular}{|c|c|c|c|c|c|c|c|c|c|c|c|c|}
\hline \multirow{2}{*}{ Isolates ID } & \multicolumn{3}{|c|}{ Temperature ranges $\left({ }^{\circ} \mathrm{C}\right)$} & \multicolumn{3}{|c|}{$\mathrm{pH}$ ranges } & \multicolumn{3}{|c|}{$\mathrm{NaCl}$ concentrations $(\%)$} & \multicolumn{3}{|c|}{ Bile salt concentrations $(\%)$} \\
\hline & $25^{\circ} \mathrm{C}$ & $37^{\circ} \mathrm{C}$ & $45^{\circ} \mathrm{C}$ & 3 & 5 & 7 & $3 \%$ & $5 \%$ & $7 \%$ & $1 \%$ & $2 \%$ & $3 \%$ \\
\hline $\mathrm{YC}_{1}$ & $*$ & $* *$ & $* *$ & $*$ & $* * *$ & $* * *$ & $* * *$ & $* * *$ & $* *$ & $* *$ & $*$ & $*$ \\
\hline $\mathrm{YCX}_{6}$ & $* *$ & $* * *$ & $* *$ & $* *$ & $* *$ & $* *$ & $* * *$ & $* *$ & $*$ & $* *$ & $*$ & $*$ \\
\hline $\mathrm{YN}_{3}$ & $*$ & $* * *$ & $* *$ & $*$ & * & $*$ & $* *$ & $* *$ & * & $* * *$ & $* *$ & $* *$ \\
\hline
\end{tabular}

$*=$ Good; $* *=$ Very good $* * *=$ Excellent

Table 6 Bile salt tolerance of the selected isolates

\begin{tabular}{l|ccc}
\hline \multirow{2}{*}{ Isolates } & \multicolumn{3}{c}{ No. of colony grown on the plates $(\mathrm{cfu} / 0.1 \mathrm{ml})$} \\
\cline { 2 - 4 } & $1.0 \%$ & $2.0 \%$ & $3.0 \%$ \\
\hline Lactococcus lactis subsp. lactis $\left(\mathrm{YC}_{1}\right)$ & 108 & 93 & 77 \\
Lactobacillus delbrueckii $\left(\mathrm{YCX}_{6}\right)$ & 270 & 168 & 95 \\
Lactobacillus plantarum $\left(\mathrm{YN}_{3}\right)$ & 380 & 238 & 148 \\
\hline
\end{tabular}

Antimicrobial Activity by Agar well Diffusion Method

The antibacterial activity of the isolates was determined by measuring the zone of inhibition expressed in $\mathrm{mm}$ in diameter (Table 3 ).

\section{Probiotic Properties of the Isolates}

In this study the selected isolates were unable to grow at high acidic $\mathrm{pH}(\mathrm{pH} 3$ and $\mathrm{pH} 2)$ but were able to grow well at lower acidic $\mathrm{pH}(\mathrm{pH} \mathrm{4,5,6}$ and 7) (Table 5). These selected isolates were also able to survive in $1 \%$, $2 \%$ and $3 \%$ bile salt concentrations (Table 5 and Table 6 ). All the selected isolates were able to grow well at temperature $25,30,37,40$, and $45^{\circ} \mathrm{C}$ (Table 5). In this study the entire selected lactic acid bacterial isolates were capable to survive $1-8 \% \mathrm{NaCl}$ concentration (Table 5). In the selected isolates, most of them were positive sugar fermenters while least numbers of isolates were negative sugar fermenters (Table 7).

Assay of Antibiotic Sensitivity Pattern

Antibiotic susceptibility pattern of selected isolates was investigated by using disc diffusion method to observe the inhibitory effect of any antibiotics against them (Table 4). 
Table 7 Sugar fermentation tests for identification of isolates

\begin{tabular}{|c|c|c|c|c|c|c|c|c|}
\hline Isolates ID & Glucose & Sucrose & Lactose & Fructose & Arabinose & Galactose & Starch & Mannitol \\
\hline $\mathrm{YC}_{1}$ & + & + & + & - & - & + & + & + \\
\hline $\mathrm{YC}_{2}$ & + & + & + & + & - & + & + & + \\
\hline $\mathrm{YC}_{3}$ & + & + & + & + & - & + & + & + \\
\hline $\mathrm{YC}_{8}$ & + & + & + & + & - & + & + & + \\
\hline $\mathrm{YC}_{10}$ & + & + & - & + & - & + & + & - \\
\hline $\mathrm{YN}_{3}$ & + & + & + & - & - & + & + & + \\
\hline $\mathrm{YN}_{6}$ & + & + & + & + & - & + & + & + \\
\hline $\mathrm{YN}_{7}$ & + & + & + & + & - & + & + & + \\
\hline $\mathrm{YN}_{9}$ & + & + & + & + & - & + & + & + \\
\hline $\mathrm{YCX}_{3}$ & + & + & + & + & - & + & + & + \\
\hline $\mathrm{YCX}_{4}$ & + & + & + & + & - & + & + & + \\
\hline $\mathrm{YCX}_{6}$ & + & + & - & + & - & + & + & - \\
\hline $\mathrm{YCX}_{7}$ & + & + & + & + & - & + & + & + \\
\hline $\mathrm{YCX}_{9}$ & + & + & + & + & - & + & + & \\
\hline $\mathrm{YCX}_{10}$ & + & + & - & + & - & - & - & - \\
\hline
\end{tabular}

Note: $+=$ Positive; - = Negative

\section{Discussion}

For the isolation of probiotic bacteria, yoghurt samples were collected from different places of Chittagong division, Bangladesh. A total of 15 bacterial cultures were isolated from the collected yoghurt samples where 3 specific isolates (Lactococcus lactis subsp. Lactis, Lactobacillus delbrueckii and Lactobacillus plantarum) were identified on the basis of their morphological and biochemical characteristics.

$\mathrm{pH}$ has dramatic effect on the bacterial growth. In this study, the growth of selected isolates was investigated in various $\mathrm{pH}$ ranges $(\mathrm{pH} 2-7)$. The study result showed that the selected isolates were grown at $\mathrm{pH} 3$ to $\mathrm{pH} 7$. The findings of this study were similar with the study result conducted by Harun-ur-Rashid et al. (2007). Lactobacillus plantarum can produce lactic acid and reduce the $\mathrm{pH}$ to values lower than 4.0 (Rao et al., 2004). This present study results exhibited that the isolates were grown well at different temperatures i.e. $25^{\circ} \mathrm{C}, 37^{\circ} \mathrm{C}$ and $45^{\circ} \mathrm{C}$, but Lactobacillus delbrueckii $\left(\mathrm{YCx}_{6}\right)$ and Lactobacillus plantarum $\left(\mathrm{YN}_{3}\right)$ were grown excellently at $37^{\circ} \mathrm{C}$ (Table-3.5). This study result was very much similar to the study driven by Sakala et al. (2002). $\mathrm{NaCl}$ has inhibitory effect on the growth of certain types of bacteria. The test isolates were able to survive at $1-8 \%$ $\mathrm{NaCl}$ concentrations and the better growth of Lactobacillus delbrueckii $\left(\mathrm{YCX}_{6}\right)$ was found at $3 \% \mathrm{NaCl}$ concentration. Murray (1990) observed that $56 \%$ of Lactococci tested were able to grow on $6.5 \% \mathrm{NaCl}$. Ibourahema et al. (2008) reported that Lactococcus lactis was the most tolerant to high $\mathrm{NaCl}$ concentration compared to the other isolates. Hoque et al. (2010) reported that Lactobacillus sp. isolated from yoghurt were able to tolerate $1-9 \%$ of $\mathrm{NaCl}$ concentrations. In this experimental study, $1-3 \%$ of bile salt concentrations were used and the isolates were able to survive at these concentrations. Bile salt concentration has an adverse effect on the growth of bacteria. The present experimental investigation showed that all the isolates were grown well at $1 \%$ bile salt. Tambekar and Bhutada (2010a) revealed that isolates were acid tolerant at $\mathrm{pH} 2$, bile salt tolerant at $2 \%$ bile salt concentration. Todrov et al. (2007) reported Lactococcus lactis subsp. lactis HV219 was grown well in the presence of $0.3 \%$ and $0.6 \%$ of bile, but not at higher concentrations which was similar to this present study. In this experimental study, the isolates were tested against some selected pathogenic bacteria to investigate the inhibitory effects of the isolates on the growth of pathogenic bacteria. The study results showed similarity with other research done by Margaretha et al. (2013). The antimicrobial properties of the Lactobacillus strains tested were very variable. Four strains of Lactobacilli sp. (Lactobacillus plantarum, Lactobacillus delbruekii, Lactobacillus. acidophilus, Lactobacillus brevis) were shown to produce a bacteriocin-like substance against Staphylococcus aureus (Nowroozi et al., 2004). The antagonistic effect of Lactococcus lactis subsp. lactis against Salmonella sp. and E. coli was investigated in the study conducted by Yateem et al. (2008) which supports the present study findings. Antibiotic susceptibility pattern of selected isolates was done by disc diffusion method. A total 10 different antibiotic discs was used to examine the antibiotic susceptibility pattern of the selected isolates. In this study Lactococcus lactis subsp. lactis $\left(\mathrm{YC}_{1}\right)$ showed sensitivity against azithromycin (23 $\mathrm{mm})$, kanamycin $(20 \mathrm{~mm})$, meropenem $(28 \mathrm{~mm})$ and amoxyclav $(21 \mathrm{~mm})$ while Lactobacillus delbruekii was sensitive to streptomycin $(21 \mathrm{~mm})$ and amoxyclav (32 $\mathrm{mm})$. On the other hand, Lactobacillus plantarum was sensitive to azithromycin $(26 \mathrm{~mm})$, kanamycin $(21 \mathrm{~mm})$, streptomycin $(22 \mathrm{~mm})$, meropenem $(37 \mathrm{~mm})$ and amoxyclav $(37 \mathrm{~mm})$. The antibiotic sensitivity pattern of the isolates was categorized in three groups i.e., sensitive, intermediate and resistant. Majority of the selected isolates were resistant to the test antibiotics. The group of probiotic strains which is resistant to antibiotics might be applied in quest of controlling intestinal tract infections for both preventive and therapeutic purpose (Tambeka and Bhutada, 2010a).

\section{Conclusion}

In conclusion, this experimental study showed that yoghurt is a potential source of probiotic bacteria (Lactobacilli and Lactococci sp.). They colonize the 
gastrointestinal tracts of humans and animals, and are present in foods such as dairy products, fermented meats, fruits and vegetables. They are also intentionally added to several probiotic products because of their potential health benefits. Finally it can be said that the selected Lactobacillus sp. and Lactococcus sp. found in this study have the potential to be used as a probiotics in near future. Further study on these isolates will help to detect the genes responsible for therapeutic activities and this type of research will help to design more probiotic agents to control numerous diseases and at the same time it will ensure the safe and healthy human civilization.

\section{Acknowledgment}

The authors would like to acknowledge the Industrial Microbiology Division, Bangladesh Council of Scientific and Industrial Research, Chittagong for the laboratory supports.

\section{Conflict of interest}

None to declare.

\section{References}

Aslam S, Qazi JI. 2010. Isolation of acidophilic lactic acid bacteria antagonistic to microbial contaminants. Pak J Zool. 42(5): 567-573.

Bauer AW, Kirby WM, Sherris JC, Turck M. 1966. Antibiotic susceptibility testing by a standardized single disk method. Am J Clin Pathol. 45(4): 493-496.

Buchanan RE, Gibbons NE. 1974. Bergey's Manual of Determinative Bacteriology. $8^{\text {th }}$ Edition. Baltimore: The Williams and Wilkins Company.

Harun-ur-Rashid M, Togo K, Ueda M, Miyamoto T. 2007. Probiotic Characteristics of Lactic Acid Bacteria Isolated from Traditional Fermented Milk 'Dahi' in Bangladesh. Pak J Nutri. 6 (6): 647-652. DOI: Doi $=10.1 .1 .485 .6268$ \&rep=rep 1

Hoque MZ, Akter F, Hossain KM, Rahman MSM, Billah MM, Islam KMD. 2010. Isolation, Identification and Analysis of Probiotic Properties of Lactobacillus spp. From Selective Regional Yoghurts. World J Dairy Food Sci. 5(1): 39-46.

Hutt P, Shchepetova J, Loivukene K, Kullisaar T, Mikelsaar M. 2006. Antagonistic activity of probiotic lactobacilli and bifidobacteria against entero- and uropathogens. J Appl Microbiol. 100: 1324-1332. DOI: doi/10.1111/j.13652672.2006.02857.x/pdf

Ibourahema C, Dauphin RD, Jacqueline D, Thonart P. 2008. Characterization of lactic acid bacteria isolated from poultry farms in Senegal. Afr J Biotechnol. 7 (12): 2006-2012. DOI: 10.5897/AJB2008.000-5048
Lilly DM, Stillwell RH. 1965. Probiotics: growth-promoting factors produced by microorganisms. Science. 147(3659): 747-748. DOI: $10.1126 /$ science.147.3659.747

Margaretha E, Lindayani, Laksmi H. 2013. Isolation and Screening Lactic Acid Bacteria from Sayur Asin Aa Starter for Probiotic Beverages. The 3rd International Conference of Indonesian Society for Lactic Acid Bacteria (3rd ICISLAB), ISBN: 978-979-19546-1-7.

Murray BB. 1990. The life and times of the enterococcus. Clin Microbiol Rev. 3: 46-65. PMCID: PMC358140

Nowroozi J, Mirzaii M, Norouzi M. 2004. Study of Lactobacillus as Probiotic Bacteria. Iran J Public Health. 33(2): 1 -7. PMCID: PMC3910179

Patil MM, Pal A, Anand T, Ramana KV. 2010. Isolation and characterization of lactic acid bacteria from curd and cucumber. Indian J Biotechnol. 9: 166-172.

Rao MS, Pintado J, Stevens WF, Guyot JP. 2004. Kinetic growth parameters of different amylolytic and nonamylolytic Lactobacillus strains under various salt and $\mathrm{pH}$ conditions. Biores Technol. 94: 331 - 337. DOI: 10.1016/j.biortech.2003.11.028

Sakala RM, Hayashidani H, Kato Y, Kaneuchi C, Ogawa M. 2002. Isolation and characterization of Lactococcus piscium strains from vacuum-packaged refrigerated beef. J Appl Microbiol. 92: 173-179. DOI: 10.1046/j.1365-2672.2002. 01513.x

Salminen S. 1996. Uniqueness of probiotic strains. IDF Nutr News Lett. 5: 16-18.

Tambekar DH, Bhutada SA. 2010a. An evaluation of probiotic potential of Lactobacillus sp. from milk of domestic animals and commercial available probiotic preparations in prevention of enteric bacterial infections. Recent Res Sci Technol. 2: 82-88.

Tambekar DH, Bhutada SA. 2010b. Studies on antimicrobial activity and characteristics of bacteriocins produced by Lactobacillus strains isolated from milk of domestic animals. Int J Microbiol. 8: 1-6.

Todorov SD, Botes M, Danova ST, Dicks LMT. 2007. Probiotic properties of Lactococcus lactis ssp. lactis HV219, isolated from human vaginal secretions. J Appl Microbiol. 103: 629639. DOI: 10.1111/j.1365-2672.2007.03290.x

Yan F, Polk DB. 2006. Probiotics as functional food in the treatment of diarrhea. Curr Opin Clin Nutri Metab Care. 9(6): 717-721. DOI: 10.1097/01.mco.0000247477.02650.51

Yateem MT, Balba T, Al-Surrayai B, Al-Mutairi, Al-Daher R. 2008. Isolation of lactic acid bacteria with probiotic potential from camel milk. Int J Dairy Sci. 3: 194-199. DOI: 10.3923/ijds.2008.194.199

Zourari JP, Accolas, Desmazeaud MJ. 1992. Metabolism and Biochemical characteristics of yogurt bacteria. J Dairy Sci Technol. 72(1): 1-34. DOI: https://doi.org/10.1051/ lait:199211 